\section{CARPENTER V. MURPHY: AN ANALYSIS OF THE SUPREME COURT ORAL ARGUMENT}

GUY S. MICHAEL

Guy S. Michael is a partner at Michael \& Carroll in Point Pleasant Beach, New Jersey.

I $\mathrm{t}$ is undeniably foolish to think you know how a Supreme Court case will come out by listening to the oral argument. As much as the oral argument in the case of Carpenter v. Murphy seems to indicate the predilections of certain of the justices, any prediction of the final result would fall into that foolish trap.

This case was well described in this publication in the past by Kathryn R.L. Rand, Steven Andrew Light, and Kevin C. Quigley. ${ }^{1}$ Rather than repeat their report, suffice it to say that the case arises out of the Oklahoma state court conviction of an Indian for killing another Indian. After a series of appeals and habeas petitions, the issue that has bubbled up to the Supreme Court is whether the murder occurred on the reservation of the Creek Tribe. If it did, then state court jurisdiction was improper. Crimes by Indians against Indians are to be tried in either tribal or federal court. If it didn't, then the murder conviction stands. Sounds simple, right? Just decide where the boundaries of the reservation are and you've got your answer. Unfortunately, it isn't that easy.

Instead, the Court is being asked to determine whether the situs of the crime is on land that Congress has "disestablished" from the Creek Reservation. The Supreme
Court in Solem v. Bartlett ${ }^{2}$ articulated the standards for disestablishment. Congress disestablishes a reservation based on three factors: the express words of any statute, contemporaneous events, and, to a lesser extent, subsequent events.

In the course of the Supreme Court arguments, each of these criteria was probed. But one more area was also extensively discussed, and it may turn out to be the most important - the practical consequences of the Court determining that the Creek retained their reservation. You see, if they do, it would include all of Eastern Oklahoma, including the city of Tulsa.

With regard to the statutory issues, Murphy argued that the text of the guiding legislation should control and that nothing in that text meets the established Solem standards for expressing the intent to disestablish the reservation. The State, of course, argued otherwise. They urged that the entirety of the various relevant statutes affecting the issue should be taken as a whole. It pointed to two main laws - the granting of statehood to Oklahoma and the congressional allotment of the tribal land ${ }^{3}$-arguing that allotment equaled disestablishment. Murphy responded specifically to the allotment argument by citing to the legislative history - arguing that allotment was only implemented when true cession of the land was rejected. Finally, the parties argued about remedies. The State claimed that if Murphy wins, the sky will fall - that the tribe would basically take over governing approximately 1.8 million people. Murphy and an amicus tribe countered that the State's projected impacts were greatly exaggerated - that interaction between states and tribes as sovereigns is commonly and effectively arranged throughout the country.

The justices' questions covered the landscape. Justices Kagan, Breyer, and Sotomayor seemed skeptical of the State's statutory argument. Justice Kagan, in particular, cited to the legislative history and appeared to read it as did Murphy, that the thrust of American policy at the time was to minimize tribal sovereignty, and she asked a number of questions
Keywords: Indian law, Indian gaming, Indian lands

DOI: $10.1089 / \mathrm{glr} 2.2019 .2326$ (C) 2019 Mary Ann Liebert, Inc.

${ }^{1}$ Kathryn R.L. Rand, Steven Andrew Light, and Kevin C. Quigley, Murphy v. Royal: Why Tribal Gaming Attorneys Should Watch This Case, 22(6) Gaming L. REv. 332-336 (July 2018), http://doi.org/10.1089/glr2.2018.2263.
${ }^{2} 465$ U.S. 463 (1984).

3“"Allotment" was a policy implemented by the Dawes Act of 1887, also known as the General Allotment Act. It authorized the president to survey the land of Native Americans and divide it into allotments for individual Indians. 
about whether this particular history had that result. Justice Sotomayor focused on the distinction between allotment and cession. She wanted to know why allotment necessarily meant disestablishment. Justice Breyer noted that the tribe had retained certain governmental authorities. He questioned why that didn't show that disestablishment had not occurred.

Chief Justice Roberts seemed dubious about whether the tribe had actually retained any real sovereign authority. In explaining what the tribal government had done, Murphy's lawyer used as his example that the tribe had created an Office of Executive Interpreter. The chief justice shot back, "In terms of ongoing functioning and relationship, the best example you have of the tribe's continuing authority is hiring an interpreter?"4 Again, recognizing the folly of trying to read the tea leaves, it still may not be a stretch to interpret this exchange as indicating the chief justice's skepticism.

Justices Kavanaugh ${ }^{5}$ and Alito both wondered whether the Court should rely on what has been the historical practice. They indicated that such practice augers against Murphy's interpretation given that state court prosecutions have been commonplace for many years. Justice Alito questioned whether this was the "dog that didn't bark." Justice Kavanaugh argued that stability was a critical value in judicial decision making. These concerns over continuity are interesting observations in the arena of Indian law given the landmark Carcieri case, ${ }^{6}$ where the Court reversed decades of statutory interpretation and prior practice in permitting land to be taken into trust and on which tribes and the government had relied.

There was substantial debate over the practical impacts of the case. Justice Alito and the chief justice asked most of the questions about this. They wondered what would happen in areas of law enforcement, taxation, alcohol regulation, and business relationships between tribal members and nonmem- bers if the tribe suddenly replaced the state. Justices Breyer and Sotomayor tried to find a method to remediate any of these problems. They both pointed out that Congress could always step in with clarifying legislation. Justice Breyer asked if the Court itself could somehow encourage the parties to come up with a cooperative plan.

There was only one question about gaming. The chief justice asked what impact any decision would have on the Indian Gaming Regulatory Act (IGRA). ${ }^{7}$ Counsel for the amicus responded that it would have no effect because the Creek Tribe already has eight gaming operations in the area. It is unclear why this was not of greater concern. While the term "Indian Country" does include Indian allotments, ${ }^{8}$ the IGRA definition of "Indian lands" does not." If, therefore, the Court's ultimate holding should rely on the land at issue being allotted land, would this not undermine the viability of the existing casinos? Further, could the present authorization for those casinos indicate that the land on which they operate has been viewed by the federal government as "Indian lands"? Would this not go to the issue of present practice? Also, in the supplemental briefing discussed further below, the State points out that the existing gaming compact between Oklahoma and the Creek Nation authorizes gaming on all Indian lands and if the Court holds that all of Eastern Oklahoma comprises Indian lands, that would greatly expand the scope of that compact.

And speaking of "dogs that didn't bark," we could put three justices in that category-Ginsburg, Thomas, and Gorsuch. They said nothing during the argument. Ginsburg because of her present physical condition; Thomas because that is his practice; and Gorsuch because he has recused himself, presumably because the case arose out of the Tenth Circuit where he had served and in which he may have participated.
${ }^{4}$ Supreme Court Transcript, at $42-8$ to 11 .

${ }^{5}$ Justice Kavanaugh, being new, has no real track record in Indian law cases. However, Indian Country is concerned that he has expressed views considered antisovereignty in the past. He both submitted a brief and wrote an op-ed taking a position in the case of Rice v. Cayetano, 528 U.S. 495 (2000), that a preference system for Native Hawaiians in Hawaii was a "naked racial spoils system."

${ }^{6}$ In Carcieri v. Salazar, 555 U.S. 379 (2009), the Court reinterpreted the phrase "now under federal jurisdiction" as the qualifying criteria for tribes who could obtain land in trust under the Indian Reorganization Act (IRA). Whereas, in the past, "now" had been deemed to mean at the time of the request, the Court changed that to say that "now" was a temporal limitation that prevented land in trust for tribes who were not "under federal jurisdiction" after 1934, the date of the enactment of the IRA.

${ }^{7} 25$ U.S.C. $\S 2701$ et seq.

${ }^{8} 18$ U.S.C. $\S 1151$

${ }^{9} 25$ U.S.C. § 2703(4). 
Presuming that Justice Ginsburg will be involved in the consideration of this case, her record is mixed. An analysis of her decisions in Indian law cases, at least until a few years ago, exhibited an early leaning against tribal interests but a growing appreciation for tribal concerns. ${ }^{10}$

Justice Gorsuch has an extensive record in tribal cases. In one, Ute Indian Tribe of the Uintah and Ouray Reservation v. Myton, he held that local governmental officials could not exercise criminal jurisdiction over tribal members on lands that were previously restored to tribal jurisdiction. ${ }^{11}$ Seemingly frustrated by the State's efforts to continue to press this issue after many prior tries, Justice, then Judge, Gorsuch began his opinion with, "We're beginning to think we have an inkling of Sisyphus's fate." Maybe Justice Gorsuch would have been more inclined toward Murphy's position.

Justice Thomas is a conundrum. For example, in his dissent from the denial of certiorari in Upstate Citizens for Equality, Inc. v. United States ${ }^{12}$ he would have preferred that the Court hear a case about the general power of federal government to take land into trust. He expressed his view that such a power was an overreach of the authority under the Constitution's Indian Commerce Clause. His view was that the Founders hardly intended to give the federal government the power to "reduce a State to near nonexistence by taking all land within its borders and declaring it sovereign Indian territory." "This doesn't sound like a Murphy voter.

On the other hand, it was Justice Thomas who wrote the opinion in Nebraska v. Parker. ${ }^{14}$ This case is somewhat similar to the Murphy case. It held that an 1882 Act that opened Indian reservation land to settlement by non-Indians did not diminish the reservation or preclude application of the tribe's liquor laws to non-tribal retailers on the opened land. Critically, he came to this conclusion by citing the standards of Solem and saying, "Only Congress may diminish the boundaries of an Indian reservation, and its intent to do so must be clear. ${ }^{15}$
Then, a week after the argument was held, the Court issued an order requesting supplemental briefing on two questions. They are:

1. Whether any statute grants the state of Oklahoma jurisdiction over the prosecution of crimes committed by Indians in the area within the 1866 territorial boundaries of the Creek Nation irrespective of the area's reservation status; and

2. Whether there are circumstances in which land qualifies as an Indian reservation but nonetheless does not meet the definition of Indian Country as set forth in 18 U.S.C. $\S$ 1151(a).

On December 5, the parties submitted their supplemental briefs. Regarding question 1, the State argues that the combination of statutes through the decades, especially the one granting statehood, conferred state jurisdiction. The tribal argument is that state jurisdiction must be explicitly granted and that none of those statutes do so. Regarding question 2, the State reverses its stance on statutory interpretation and instead of reading them implicitly as it did for question 1, it says that the statutory definition of Indian Country is clear and must include Indian reservations. The tribal interests somewhat agree, but go a step further. They say that it is well settled that all reservations are within the definition of $\S 1151$ (a) because they are, in the words of the section, "under the jurisdiction of the United States Government." So, they say, reopening that question now would lead to a "stampede of litigation" that would upset a very foundation of Indian law.

It looks from these questions as if the Court may be trying to find a way out of this case by holding that the land at issue could still be a reservation but not Indian Country. That way, it would give the state courts jurisdiction but not impact the reservation boundaries. Solomonic, but the parties do not seem to have embraced it.

There are also some significant gaming aspects to these supplemental questions. The question of what

\footnotetext{
${ }^{10}$ Carole Goldberg, Finding the Way to Indian Country: Justice Ruth Bader Ginsburg's Decisions in Indian Law Cases, 70(4) Оноо Sт. L.J. 1003-1035 (2009).

${ }^{11} 835$ F.3d 1255 (10th Cir. 2016).

${ }^{12} 199$ L. Ed. 2d 372 (2017).
}

\footnotetext{
${ }^{13} 199$ L. Ed. 2d 372 (2017).

${ }^{14} 194$ L. Ed. 2d 152 (2016).

${ }^{15} 194$ L. Ed. 2d 152, 154 (2016) emphasis added.
} 
the phrase "under the jurisdiction of the United States Government" means rings familiar to practitioners of Indian gaming law. Carcieri redux? ${ }^{16}$ All we need is another battle over the meaning of those words.

Despite my stated belief that a prediction would be foolish, I am now too tempted. This would be my guess at an outcome. If the Court wanted the result enunciated by the Tenth Circuit - that three million acres and 1.8 million people in Oklahoma may now be under tribal jurisdiction, it did not have to take the case. So, it would seem that the practical impacts are what the Court wants to deal with. Therefore, my best guess would be that the Court will do one of three things: either adopt the view implicit in its supplemental questions; or, whether by remand or otherwise, direct the parties to develop a resolution; or, finally, suggest that Congress deal with it. In other words, punt.

I make these predictions with one big caveat-as I write this, I am in next to last place in my football pool. 